\title{
Land Tenurial System Influence Among Smallholder Farmers' Climate Smart Agriculture Technologies Adoption: Sub-Sahara Africa. A Review Paper
}

\author{
Petros Chavula $^{1 *}$ \\ School of Agriculture, Haramaya University Department of Climate-Smart Agriculture \\ Africa Center of Excellence for Climate Smart Agriculture and Biodiversity Conservation \\ PO box 138, Haramaya, Ethiopia \\ Benson Turyasingura ${ }^{2}$ \\ Kabale University Plot364 Block 3 Kikungiri Hill, Department of Environmental Science \\ Kabale Municipality Uganda
}

\begin{abstract}
This review paper is not sponsored by any organization it is the autho's initiative.
\section{Abstract}

Climate variability and extremes are very a great deal affecting lives in Sub-Saharan Africa. Nevertheless, where people are poor and vulnerable like in this region, these factors can add greatly to the hardship of their lives. Over the years climate versions and climate change are amongst the challenges the world face together with SubSahara Africa nations. Climate-smart agriculture technologies provide efficient answers (i.e. increased productivity more advantageous family income, resilience and decreased greenhouse gasoline emissions). Smallholder farmers are the primary and secondary pillars of the agricultural sectors', especially in low-income countries. Therefore, their involvement in climate change mitigation and adaption moves is imperative. Climatesmart agriculture applied sciences are looking for a manageable and greater secure earnings sustainability. This study aims to provide an overview of how the land tenure system affects climate-smart agriculture technologies adoption in Sub-Sahara Africa countries. Based on findings from selected articles, socioeconomic factors (e.g. access to credit, poor extension services, and inputs) and institutional factors (e.g. land tenure system, land scarcity) are major challenges to climate-smart agriculture technologies adoption, the major message is sitespecific due to heterogeneity of smallholder farmers. Furthermore, it is worth mentioning land-use security is a critical factor of climate-smart technologies adoption among smallholder farmers. Full-time farming is a commitment that positively beautifies the adoption of climate clever agriculture mainly if the land is tightly closed and some practices take greater than one year to comprehend advantages (i.e. to achieve economic and environmental benefits).
\end{abstract}

Keywords:Climate-smart agriculture, climate, agriculture, land, tenure, adoption, sustainability.

DOI: $10.7176 / \mathrm{JBAH} / 11-23-03$

Publication date: December $31^{\text {st }} 2021$

\section{Introduction}

There is a scientific consensus that concentrations of greenhouse gases in the atmosphere are growing due to human activities, inflicting world climate exchange and that the inevitable world warming will have fundamental impacts on the climate worldwide(Fischer et al., 2002). The Intergovernmental Panel for Climate Change [IPCC] report (2018) dispels any uncertainty about climate trade and gives specified projections for the twenty-first century, which suggests that world warming will continue to accelerate. Consequently, the effects of global warmings, such as disruptions in food and water systems, will adversely affect improvement and livelihoods and will most likely add to the challenges local weather exchange already poses for poverty eradication. This is likely to have an impact on the social, as well as cultural and economic development of rural poor communities and agricultural productivity, particularly in Sub-Saharan Africa(CIAT \& World Bank, 2017).

Agriculture performs an important role in the economy of growing countries, and it is the mainstay of food, profits and employment for the rural populace (FAO, 2018). The sector money owed for a comparatively small share of the international economy however remains central to the lives of many human beings in the world (FAO, 2018). In 2012, of the worlds' 7.1 billion people, an estimated 1.3 billion (19\%) were immediately engaged in crop and animal production things (WFP, 2018). The agricultural sector alone, provide an approximation of $70 \%-80 \%$ of employment opportunity to the global population and accounts for more than $40 \%$ of gross domestic product (GDP) from exports for most agricultural dependent countries( State \& Food, 2002;Padgham, 2009). Hence a vibrant agricultural sector, either at the local or at global level, is fundamental in securing poverty reduction, food security and nutrition leading to the attainment of sustainable development goals numbers number one (1) and two (2) which are 'no poverty' and 'Zero hunger' respectively. Statistics indicate that a huge percentage of agriculture-dependent countries lies in the Least Developed Countries (LDCs) 
that includes Sub-Saharan African countries. According to FAO (2016), Sub-Saharan Africa alone has more than $60 \%$ smallholder farmers and about $23 \%$ of GDP in Sub-Saharan Africa countries come from agriculture. In the year 2016 Food and Agriculture Organization (FAO), established that middle and low-income countries in SubSaharan Africa, largely depend on agriculture to achieve their economic growth. It further states that $35 \%$ of GDP comes from the agricultural sector, which also employs about $70 \%$ of the population(Ghattas \& FAO, 2014). The agricultural sector has to be prioritized to obtain financial growth, poverty reduction, food security, a good diet and creating employment opportunities. Hence, SSA countries' governments through policy reforms of agriculture and livestock focus on increasing diversification of crop and livestock production in addressing challenges that have worsened due to rapid population increase and climate change impacts. Population increase has increased demand for food and settlement area resulting in a tremendous amount of pressure on the land and land-use systems(N. Jama et al., 2019). Whereas climate change has negatively affected agricultural production due to changes in climatic conditions that negatively impact the agricultural systems. Therefore, enhancing the agricultural sector ensures food security and contributes to the direction of a nation's economic boom an indispensable deliberate policy that supports the attainment of SDGs especially goals number one (1) and two (2)(Kabwe et al., 2009).

In Sub-Sahara Africa (SSA) countries, smallholder farmers' input accounts for more than $70 \%$ of rain-fed agricultural activities whether it is crop and/ or animal production (State \& Food, 2002). Most of these smallholder farmers are in a state of adverse poverty and are unable to meet the expenses of industrial inputs to improve production (Mugure et al., 2013). The high price of inputs has contributed to meals insecurity and poverty confronted by smallholder farmers(Nkhuwa et al., 2020). Additionally, over-dependence on rain-fed agriculture by smallholder farmers means climate change poses a great challenge as far as agricultural production is concerned(Kabwe et al., 2009). Arslan et al. (2015) espoused that the effects of climate exchange on crop manufacturing are no longer limited to total rainfall and common temperature effects. For instance, a "false start" to the wet season, droughts, flooding or erratic rainfall can be disastrous for crop establishment. Further to that, the variations in variability to impacts depend on location, adaptation capacity and other socioeconomic and development factors(White et al., 2016). The vulnerability of poor farmers to climate change and extreme weather events is further worsened by lack of access to land due to the traditional land tenurial arrangements, adequate water, low levels of technology holdouts, and education and institutional mismanagement(Aruho Bamanyaki Patricia, 2020). These challenges contribute to production problems compounded by environmental degradation and loss of valuable natural assets such as woodlands and forests, which directly and indirectly support agricultural production(Amoussouga Gero \& Egbendewe, 2020). According to Arslan et al. (2015) traditional farming systems such as shifting cultivation and low rate of adoption of strategic natural resources management technologies leads to land degradation and loss of soil fertility. The need to improve soil fertility and to adopt new farming technologies has become a very important issue in development policies under the agricultural reforms in most developing countries (Arslan et al., 2015).

To combat loss of soil, fertility and folder shortage governments and non-governmental organizations have stimulated smallholder farmers to climate-smart agriculture technologies( Chijioke et al., 2011;Kaliba et al., 2018;Branca et al., 2019). Climate-smart agriculture technologies (e.g. organic farming, agroforestry, conservation agriculture, multi-cropping) are tailored to increase household income agriculture productivity, climate change resilience and mitigation of the contribution of tree crops in farming systems and less synthetic fertilizer usage (B. Jama \& Zeila, 2005).

Hence, agroforestry is the deliberate integration of multipurpose tree species and shrubs with crops and livestock to maximize production (B. Jama \& Zeila, 2005). In distinction conservation agriculture is a strategy to manage agro-ecological systems for improved, sustained productivity, elevated profits, food safety while preserving, bettering the useful resource base and the environment (B. Jama \& Zeila, 2005). Conservation agriculture improves the efficient use of natural resources through integrated management of available resources combined with external inputs similar to agroforestry. Agroforestry and conservation agriculture are sustainable land-use structures that largely assist in addressing land degradation and loss of soil fertility(Islam et al., 2015). The mixture of agroforestry and conservation agriculture applied sciences maximizes the benefits accruing from them and is mutually referred to as Conservation Agriculture with Trees (CAWT) (Farooq \& Siddique, 2015). CAWT advantages the environment by way of counteracting fodder shortages, soil degradation, and soil health and enhancing soil first-rate (resource-efficient agriculture technologies). According to Jama et al. (2019) agroforestry tree species, growing on farmland reduces water losses, help to retain water for crops and provide protection to watersheds. Integration of agroforestry tree species into agriculture systems can capture a much larger amount of rainfall(Islam et al., 2015).

Despite the promotion of climate-smart agriculture technologies (e.g. organic farming, agroforestry, conservation agriculture, multi-cropping) across the world, adoption levels are low(Mwangi \& Kariuki, 2015). Adoption rates for (e.g. organic farming, precision agriculture, response, conservation agriculture, agroforestry) have not been as fast as desired( Nyasimi et al., 2017;Kaliba et al., 2018). However, empirical studies conducted 
in Latin America, Burma, Africa (Sub-Saharan Africa countries) and India aimed at establishing factors influencing climate-smart agricultural technologies adoption among smallholder farmers (Coulibaly et al., 2017). Therefore, studies have analyzed factors affecting the adoption of sustainable agriculture. These empirical studies yielded socio-economic challenges (e.g. lack of germplasm, awareness, education, extension services, on-farm income, off-farm income, size of household, age, education, family size, assets owned) and institution factors (e.g. land tenure system, farmland size). Institutional factors also serve as a disincentive to CSATs adoption by smallholder farmers (Islam et al., 2015).

Most smallholder farmers are in rural areas of SSA countries (Islam et al., 2015). Approximately $80 \%$ of the rural population is predominantly agrarian engaged in subsistence farming living under customary land. Customary land is considered tenure secure despite the absence of formal written documents or title deeds(Peters, 2007); Mugure et al., 2013). Secure land tenure is, therefore, a critical factor in the adoption and adaptability of sustainable agricultural technologies (e.g. agroforestry, conservation agriculture, response agriculture, precision agriculture). Peters (2007) alluded that land tenure is a key factor to economic development (e.g. agricultural production and productivity, natural resource management, management of grazing lands, management of flood plains, and irrigated croplands and in rural development). According to (Sosthenes et al, 2012) tenure security is an element of property rights. Property rights are legal structures that in reality define rights held through an individual; simply declaring his or her possession of the land. Therefore, land as the property stays one's property for some years. Property (land) rights are an-overlapping bundle of rights towards a natural resource among other things.

There are many mixtures of property rights about (Hagos, 2013) land resources :(1) Use rights- right to get right of entry to the aid or exploit sources for financial gain for occasion grazing cattle on the common pasture. (2) Control rights stop others from getting access to the field and alienation (e.g. exclusion of others). However, individuals and communities frequently have rights of access, use and sometimes decision making on land that is official government (state) land. People similarly use rights on common property, whereas the state may have some regulatory, management or decision rights over it(Sosthenes et al, 2012). Land rights structure has a corresponding set of costs and benefits that are interlinked to the resource underuse (Sosthenes et al, 2012). Confering to Peters (2007) land resources under control and use rights benefit families from any developmental projects.

In SSA, countries state and customary institutions have been principal mechanisms for the creation and allocation of rights in societies. According to Peters (2007) in SSA communities land tenure is in different ways (i.e. free-hold, lease-hold and communal). Communal tenure refers to the right of commons that exist within a community where each member has a right to use independently the holdings of the community (Shittu et al., 2018). For instance, individuals of a community might also have the right to graze animals on a frequent piece of land. According to (Feder \& Feeny, 1991) defined leasehold tenure is access to land by paying rent to the owner depending on the relationship. Whilst freehold tenure as land belonging to an individual or corporation with full perpetual rights situation. In addition, privately-owned land ought to be sold, collateralized and developed.

Conferring to (Hagos, 2013) avowed that land in Africa could be fragmented if privately owned. Meaning that land rights can be passed on from one era to another. Therefore, land fragmentation follows certain inheritance norms of a clan and/or family. The Head of households is responsible for allocating land to children with no clear boundaries and title deeds. This prevents beneficiaries from planting perennials (e.g. tree species). This is because the planting of trees symbolizes ownership of a portion of land. After all, trees are long-lasting (Mugure et al., 2013). In such cases, the head of the family has all the rights of land ownership and tree tenure.

In Sub-Saharan African countries consisting of Ethiopia, Zambia, Kenya, Uganda, land tenure is insecure. This is specifically actual for the terrible consisting of youths, the aged, socio-class and female who are now not allowed to personal usual land(Adaptation : Does Stronger Tenure Security Increase Farmer, 2018). Men (father or husband) determine women's ownership of land. Most of the girls are evicted upon the demise of their spouse (E, 2019). Therefore, land tenure arrangements affect farmers' capacity to borrow, extend or exit with a lump sum via land market transactions and have an effect on incentives for land enhancement and/or development

\section{Literature Review}

\subsection{Agriculture technology adoption}

The cause of this part is to highlight theoretical principles and levels involved in the adoption of new technology through farmers. However, farmers are into subsistence farmers, emergent farmers and commercial farmers.

2.1.1 Basic concepts of technology adoption

The basic concept of technology adoption can better be conceptualized by understanding distinctions between technology diffusion and technology adoption. Technology diffusion is regarded as the spread of new technology across the populace over time. Whilst technology adoption is measured at one point in time in a certain area. However, (Dialla, 1992) argued that new technology adoption is mostly accompanied by two processes is the process of diffusion and adoption. 
Therefore, technology can be defined as an idea, practice or objective that is perceived to be new using a team of human beings or community. Adoption of technology is simply the use of the newly introduced technology by the community or people at a given time(Kaliba et al., 2018). While technological know-how diffusion is a method via which technological know-how is communicated through positive viable channels over time amongst members of a social system (Kaliba et al., 2018). Technology diffusion has been summarized using four key elements(Dialla, 1992): (1) social system, (2) period over which a social system adopts new technology, (3) the technology represents a new idea, practice, or objective being diffused, (4) communication channels that represent the flow of information on new technology through extension/outreach activities.

Adoption of improved technology can be categorized into individual or aggregate adoption (Kaliba et al., 2018). Therefore, individual adoption is a degree of the usage of an added technology in the long run such that a farmer attain full information about the technology and its potential. Whereas combination adoption is defined as the procedure to spread a brought technological know-how inside a region.

The application of the concept of adoption in empirical studies, therefore, requires making a distinction between technologies, which are divisible and non-divisible. This is because oftentimes the nature of the technology dictates the terms on which adoption is conceptualized and analyzed.

2.1.1.1. Technology adoption stages

According to (Kaliba et al., 2018) a developed technology adoption model generalized the use of it in his book entitled "Diffusion of Innovations". The model indicates that the first people to use new technology are referred to as innovators, accompanied by early adopters. Furthermore, comes to the early and late majority and eventually the last to adopt are known as laggards(Dialla, 1992). In line with (Kaliba et al., 2018) defined the categories as follows:

Innovators: innovators are the first humans who undertake a given technology. These people are willing to take risks, have terrific monetary liquidity, are very social and have the closest contact with scientific sources and interactions with different innovators.

Early adopters: Early adopters are a crew of humans normally young in age, with higher social status, advanced education, and are extra socially ahead than late adopters that are discrete in adoption alternatives than innovators.

Early majority: These individuals undertake a technology after various degrees of time. The term of adoption is pretty longer than innovators and early adopters. The early majority tends to be slower in the adoption process, have a common social status, contact with early adopters and not often keep positions in any management system.

Late majority: Comprises of humans that adopt technological know-how after the common member of the society has adopted it. These individuals approach an intended technology with scepticism from or after a majority of different people have adopted the technology. This category has individuals who are sceptical about technologies, have little financial resources, and have very little opinion on leadership.

Laggards: Laggards are the final to adopt a given technology. Laggards are folks who exhibit little opinion of leadership; commonly averse to risks and tend to be advanced in age. Therein, laggards are typically targeted on traditions; probable have to decrease social status, lowest economic cash flow, in contact with solely household contributors and shut friends.

2.1.1.2. Stages of technology diffusion

According to Abera (2008) categorised the adoption choice method into five special stages: (1) Knowledge: in this stage, a man or woman is exposed to knowledge about the technological know-how ensuing in ideas of how it functions; (2) Persuasion: character varieties a beneficial or destructive mindset in the direction of the technological know-how at this stage. Therefore, individualistic of this stage makes it hard to collect empirical evidence (Sahin et al., 2006); (3) Decision: a person engages in activities that lead to a desire to adopt or reject a newly introduced technology; (4) Implementation: at this stage individuals put science into practise depending on the situation; (5) Confirmation: this is a most critical stage above all. Individuals evaluate the results of technology decisions already made and decide whether to continue using the technology (Rahman et al., 2008). Intra and interpersonal confirmations are made, which involve group decisions about the technology adoption.

2.1.1.3. Speed of technology adoption

Access and availability of information play an important role in the speed of technology adoption by farmers (Sahin et al., 2006). Farmers' rely on the facts or preceding expertise about traits of a technology that influences the rate at which humans undertake new technology. Speed of technology adoption is therefore the relative to speed to adopt certain technology encompassed by five intrinsic characteristics of the new technology (Sahin et al., 2006). The speed of technology adoption is the length of time required by community members to adapt to new technology. New technological know-how possesses characteristics such as relative advantage, compatibility, complexity or simplicity, divisibility and observability(Sahin et al., 2006). Relative gain refers to how increased the new technology is over the preceding generation. Compatibility is the level at which science has assimilated into an individual's life. Simplicity is the stage of perception; if folks identify a new science to 
be intricate to use, it is no longer adopted (Sahin et al., 2006). Divisibility refers to how easily the technology may be experimented with or trialled by innovators (Kaliba et al., 2018). Therefore, if a person can test the technology and person will be more in all likelihood to undertake it. Lastly, observability is the extent to which a technology is visible to others.

2.1.1.4 Concept of planned behaviour

The concept of planned behaviour (CPB) originated from a social psychology study. This theory explains the intentions of an individual to perform certain key factor behaviour over time. According to Fink (2015) concepts assume that intentions capture motivational factors that influence behaviour change and depends on beliefs that link behaviour to given results and perceived social pressure to act. Therein, an individual's intentions have an impact on behavioural overall performance to a positive extent with control over it. However, the concept of planned behaviour plays role in understanding farmers' intentions, which has significant implications on improved technology adoption (Fink, 2015). The concept of planned behaviour provides a theoretical framework model tool appropriate for understanding smallholder farmers' beliefs, incentives and how information influences behavioural change(Kaliba et al., 2018). Smallholder farmers' attitudes, social strain and overall performance of a given technology; are examined to understand what motivates farmers to adopt or drop a brought technological know-how. For that reason, evaluation of agroforestry technology adoption in different parts of the world was important following the concept of planned behaviour among farmers. The evaluation intended to find out if agroforestry technologies adhere to farmers' social settings and meet their goals.

2.1.1.5. Concept of choice

Concerning choice theory, people in their everyday life make choices concerning what is available for them. For that reason, rational choice is a process of choosing the preferred option from available alternatives/preferences. Therein, Fink (2015) alluded that people tend to choose the preferred option of technology or services depending on one's criterion that is important to them. Rational choice theory is a model of optimization having one assumption that states "given two bundles of good ' $\mathrm{X}$ ' and ' $\mathrm{Y}$ ', a consumer will choose bundle ' $\mathrm{Y}$ ' if it contains at least more of one good and not less than of the other goods in that bundle. This concept explains why farmers may decide to adopt agroforestry technology to conventional agriculture or other agricultural practices (Bank \& Bank, 2008). Agroforestry technology contains traits (e.g. improvement of soil fertility, reduces crop failure, soil erosion control, provision of fodder, provision of fruits, eco-system services, guaranteed sustainability, easy to use, crop diversification, to mention a few) compared to other agricultural practices. In that vein, farmers will tend to prefer agroforestry technologies to other agricultural technologies.

\subsection{Land tenure impacts on climate-smart agriculture adoption}

The World Bank and FAO in their development and climate change report indicated that CSA could address climate change and help achieve global sustainable development goals. Despite the efforts of WB and FAO in promoting CSA across the globe, it is faced socioeconomic and institutional factors regarding uptake. Therefore, sociocultural factors, including customs, beliefs and values within communities of SSA countries influence smallholder farmers' adoption of CSATs(Feder \& Feeny, 1991;Lavers, 2018).

In SSA, studies to determine the influence of land tenure and property rights on the adoption of new agriculture technologies have been conducted in Africa(McCarthy \& Brubaker, 2014). These studies targeted rural areas of most SSA countries because that's where most of the farming households are based (e.g. Kenya, Tanzania, Zambia, Senegal, Nigeria, Ethiopia and Cameroon). Fortunately, findings have nearly been the same.

Therefore, Tsige et al. (2020) recognized many limiting elements of CSATs amongst smallholder farmers in Ethiopia (i.e. land shortage exacerbated through land insecurity, understanding gap, getting admission to credit access and resources). Smallholder farmers additionally provided one of a kind selections pertaining CSATs adoption: restoration of marginal lands, microfinancing, and understanding switch and resource sharing. Lastly, preferences require robust coverage help and inclusive land reforms. On the other hand, (Asrat \& Simane, 2018) recognized the same constraints of CSATs adoption in Ethiopia as the different empirical research (i.e. information gap, lack of information, land scarcity, and get admission to credit). The two studies also complimented (Khoza et al., 2019) findings that women and youth smallholder farmers are constrained to CSATs decision adoption and land ownership.

Based on the evaluation of 601 interviews in one-of-a-kind agro-ecological zones of Malawi, Mozambique, Zambia, and Zimbabwe (Makate, 2019) confirmed that farm size, land rights and financial circumstances play a vital role in CSATs adoption of SSA smallholder farmers not only supplying understanding switch but also aid pooling. Moreover, cost chain improvement and higher market get right of entry can extensively assist them as well.

However, (Nyasimi et al., 2017) highlighted various barriers to CSATs adoption in Tanzania among smallholder farmers (i.e. land tenure arrangements and ownership rights, knowledge intensity, high investment costs, labour intensiveness, awareness gap). As for, (Mutua-Mutuku et al., 2017) alluded that tenurial issues, expensiveness and labour intensive often holdbacks CSATs adoption. Similarly, the introduction of novel 
technologies requires extensive knowledge switches and ample time. Wherefore, access to inputs and resources is key, as that make CSATs adopt a manner even if financial resources are barely available. Clear gender inequality is proven among girls and adolescence smallholder farmers not only go through extra from one-of-akind adoption constraints but are also denied get entry to land ownership and the proper to determine on CSA adoption.

In the year 2017 food and agriculture, organization (FAO) established personal ownership of landencouraged farmers to invest in sustainable agriculture (e.g. conservation farming, soil conservation and perennial farming) in Cameroon. In particular, long term land tenure and property rights are critical for conservation farming and agroforestry initiatives, and other agricultural enterprises(Kuntashula et al., 2015). Consequently (UNDP, 2009) stated that in most parts of Africa women and youths contribute to about $87 \%$ of the workforce towards food production and raw material for processing. Therefore, the conference held in Kenya emphasized the active inclusion of women and youths in land allocation, and other developmental projects. However, farming households are based in customary land of which land is the most important property but women access is usually determined by men (father or husband). Wherefore, the land resource is a most important property community across the world especially for SSA countries(Shittu et al., 2018).

According to Mugure et al., (2013), a study in the Nambale District of Kenya proved that land ownership influenced the adoption of CSATs (e.g. agroforestry, conservation agriculture). Research findings also attested farmland size and land ownership determines the kind of technology to adopt (Mugure et al., 2013). As family size increases, their share of land gets smaller since they have to pass on portions to the younger generation and more to their sons. The study narrowed that land ownership is frequently vested in men. This makes women plant their desirable crops on a parcel of land only when it is given to them as a gift(Mugure et al., 2013). The study results indicated that the majority of farmers $(70 \%)$ had less than 7 acres, which is relatively small compared to household size. As the measurement of the land increases, the acreage allocation to tree planting increases. Farmers with large farm sizes will spare larger portions of land to plant trees compared to their counterparts with small parcels of land(Ajayi et al., 2011). Additionally, farmland size, household size and insecure land tenure influence CSTs (e.g. agroforestry and conservation agriculture) adoption by subsistence farmers in rural areas(Mugure et al., 2013).

Meanwhile Sosthenes et al, 2012) argued that the low rate of agroforestry adoption was not farmers' resistance to change but due to complex and sensitive land tenure systems in Tandai Village of Uluguru Mountains of Morogoro rural district, Tanzania. Moreover, the researchers concluded that adoption of agroforestry practices in the Uluguru Mountains can be realized if agroforestry systems are promoted to areas that take account of land-tenure systems in the area and farmland size that determine land-tree relationships.

\subsection{Conceptual framework}

Agriculture in developing nations should bear a considerable transformation if it is to meet the developing and interconnected challenges of crop failure, animal diseases, pasture shortage and climate change (Hatfield et al., 2011). These challenges are evident in Sub-Saharan African countries, where the population was expected to grow by one billion in 2010 that is between 1.9 to 2.4 billion people by 2050(Intergovernmental Panel on Climate Change (IPCC), 2018). To combat these challenges faced by smallholder farmers there is a need to promote climate-smart agriculture technologies. These technologies are, tailored to address agricultural production and productivity challenges (e.g. yield variability, diverse climatic conditions) experienced by smallholder farmers in developing countries( (Padgham, 2009; Chijioke et al., 2011).

Despite the implementation and marketing of climate-smart agriculture projects, smallholder farmers have a poor adoption rate. According to the examined empirical studies, socioeconomic and institutional variables explain the low uptake of CSATs implementation (Chijioke et al., 2011; White et al., 2016). Therefore, socioeconomic factors include livestock ownership, farming implements, farmland size among other important factors. Institutional factors comprise access to credit, extension services, and land tenure system among others. Below is an illustration in figure 1 . 


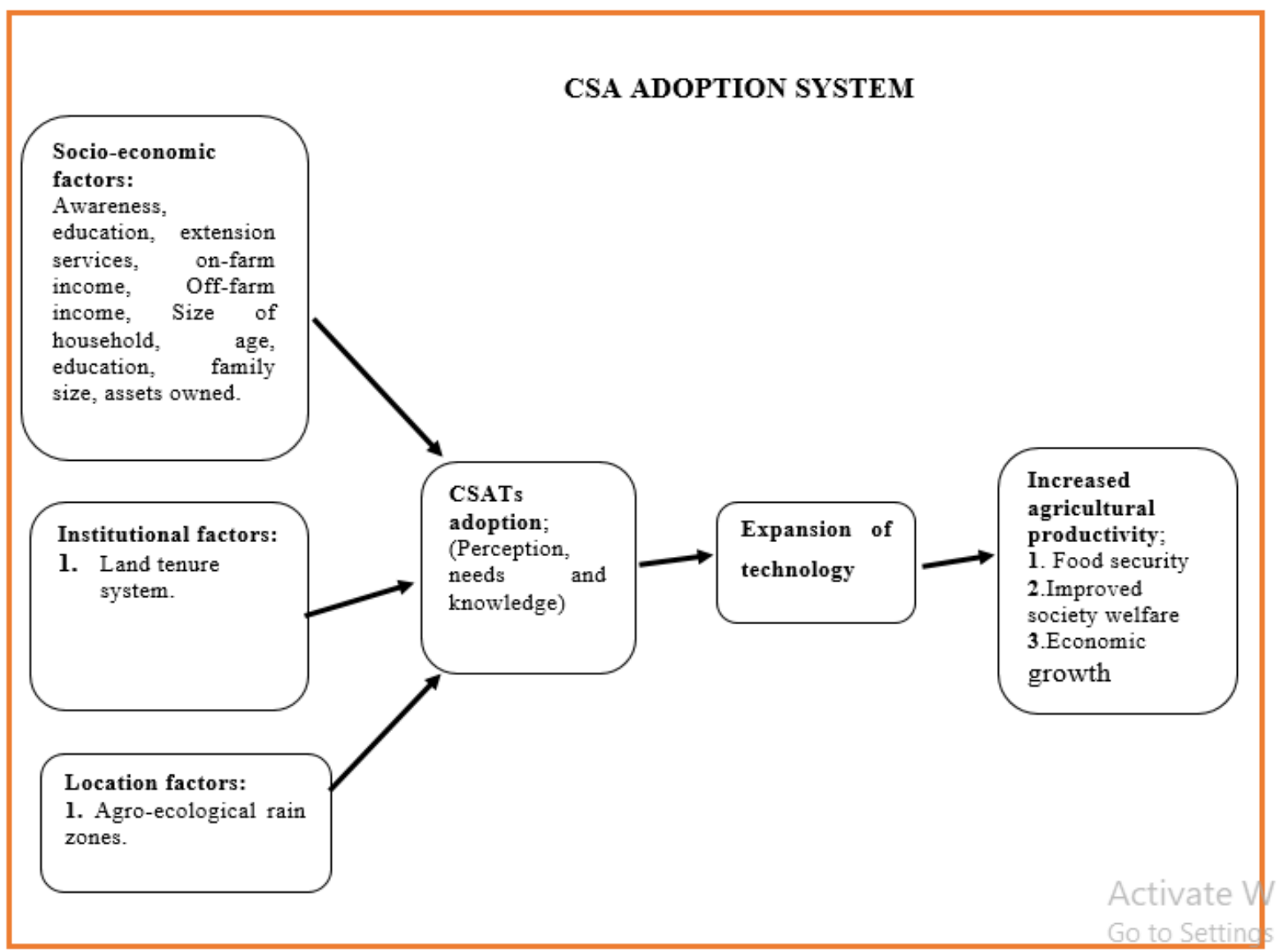

Figure 1: Conceptual framework of the review. Adopted from Duvel, (1994).

\section{Conclusion and Recommendation}

\subsection{Conclusion}

The land tenure structure encourages smallholder farmers to invest more in their land to increase agriculture productivity and production (i.e. crops and livestock). Smallholder farmers with land utilize a wider range of management approaches and adopt new agricultural technology that interests them. Climate-smart agriculture technological know-how adoption is incredibly established on the farmland dimension because it is related to the farmer's choice to establish a technology approximately for more than three farming seasons. Land ownership offers a whole lot of authority to smallholder farmers. It gives room for a smallholder to make long term plans and strategies of what he/she wants to do on a piece of land. Farmers who rent land or tenants, on the other hand, do not. As a result, tenant farmers are required to utilize tactics that enhance short-term productivity, even if it means sacrificing future property to profit from things like restored soil fertility and grazing availability. Since there is no guarantee that, they will occupy the piece of land for a long time and reap the benefits. Therefore, secure land tenure has a positive relationship with farming households adopting agroforestry practices and conservation farming by smallholders.

\subsection{Recommendation}

CSATs holds the promise of achieving important development objectives specifically reducing poverty, improving climate change resilience, and increasing adaptation to climate variations. The limited adoption of CSATs to date is at least partly the result of institutional environments that do not provide sufficient incentives to smallholder farmers to uptake them. Therefore, interventions that increase security over land resources by strengthening the bundle of rights that smallholder farmers hold can help reduce some of the risks by increasing the likelihood that farmers will be able to successfully adopt CSATs and capture future income benefits. However, land reforms and strategies to support CSA can be built to address underlying tenure weaknesses.

The following proposals for improving land tenure systems may aid in CSAT adoption:

$>$ Support efforts to enhance women's rights with attention to how productive assets are divided upon divorce or death of husband, fathers, or brothers to increase their ability to capture future benefits necessary to incentive investment.

$>$ Support programmes that allow farmers to register and file land rights in a greater cost-effective, 
participatory manner, drawing on the local expertise of legit land rights to make bigger assurance.

$>$ Support efforts to proactively register and record the land rights of women and other vulnerable groups, such as migrants, who participate in CSA projects to increase assurance and prevent elite capture.

$>$ Allow for greater flexibility in the transfer of rights including those governing temporary (i.e. rental or leasehold) and permanent (e.g. sale) transfers to increase opportunities for landholders to capture the full value of an investment.

\section{References}

Abera, H. B. (2008). CHAPTER 3 LITERATURE REVIEW : AGRICULTURAL TECHNOLOGY ADOPTION 3 . 2 Basic concepts and theoretical foundations of adoption analyses. Technology, 47-76.

Adaptation: Does Stronger Tenure Security Increase Farmer. (2018).

Ajayi, O. C., Place, F., Akinnifesi, F. K., \& Sileshi, G. W. (2011). Agricultural success from Africa: The case of fertilizer tree systems in Southern Africa (Malawi, Tanzania, Mozambique, Zambia and Zimbabwe). International Journal of Agricultural Sustainability, 9(1), 129-136. https://doi.org/10.3763/ijas.2010.0554

Amoussouga Gero, A., \& Egbendewe, A. Y. G. (2020). Macroeconomic effects of semi-subsistence agricultural productivity growth: Evidence from Benin and extension to the WAEMU countries. Scientific African, 7. https://doi.org/10.1016/j.sciaf.2019.e00222

Arslan, A., Mccarthy, N., Lipper, L., Asfaw, S., Cattaneo, A., \& Kokwe, M. (2015). Climate Smart Agriculture? Assessing the Adaptation Implications in Zambia. Journal of Agricultural Economics, 66(3), 753-780. https://doi.org/10.1111/1477-9552.12107

Aruho Bamanyaki Patricia. (2020). Barriers and opportunities for gender-responsive climate-smart agriculture adoption in Northern Uganda. Fao 2014, 7.

Asrat, P., \& Simane, B. (2018). Farmers' perception of climate change and adaptation strategies in the Dabus watershed, North-West Ethiopia. Ecological Processes, 7(1). https://doi.org/10.1186/s13717-018-0118-8

Bank, T. I., \& Bank, T. W. (2008). Agriculture Development (Issue c).

Branca, G., Paolantonio, A., Cavatassi, R., Banda, D., Grewer, U., Kokweh-Larbi, K., \& Lipper, L. (2019). Climate-Smart Agriculture Practices in Zambia: An Economic Analysis at Farm Level. SSRN Electronic Journal, October, 20-29. https://doi.org/10.2139/ssrn.3305891

Chijioke, O. B., Haile, M., \& Waschkeit, C. (2011). Implication of Climate Change on Crop Yield and Food Accessibility in Sub - Saharan Africa. ZEF Center for Research and Development., 1-31.

CIAT, \& World Bank. (2017). Climate-Smart Agriculture in Zambia. CSA Country Profiles for Africa Series. https://ccafs.cgiar.org/publications/climate-smart-agriculture-zambia

Coulibaly, J. Y., Chiputwa, B., Nakelse, T., \& Kundhlande, G. (2017). Adoption of agroforestry and the impact on household food security among farmers in Malawi. Agricultural Systems, 155, 52-69. https://doi.org/10.1016/j.agsy.2017.03.017

Dialla, B. E. (1992). The adoption of soil conservation practices in Burkina Faso: the role of indigenous knowledge, social structure and institutional support. Iowa State University DR.

E, E. N. (2019). Impacts of the women-in-agriculture (WIA) extension programme on women' $s$ lives; implications for subsistence agricultural production of women in Imo State, Nigeria. July.

FAO. (2018). Fao Publications Catalogue 2018 Fao Office for Corporate Communication. 110.

Farooq, M., \& Siddique, K. H. M. (2015). Conservation agriculture. Conservation Agriculture, 1-665. https://doi.org/10.1007/978-3-319-11620-4

Feder, G., \& Feeny, D. (1991). Land Tenure and Property Rights: Theory and Implications for Development Policy. http://wber.oxfordjournals.org/

Fink, M. (2015). E T \& P. March 2020. https://doi.org/10.1111/etap.12056

Fischer, G., Shah, M. M., \& Van Velthuizen, H. T. (2002). Climate change and agricultural vulnerability.

Ghattas, H., \& FAO. (2014). Food Security and Nutrition in the context of the Global Nutrition Transition. Food and Agriculture Organization of the United Nations, April, 1-15. http://www.fao.org/economic/ess/essfs/voices/en/

Hagos, H. G. (2013). Land policy and governance reforms and agricultural transformation. November, 8. http://ebrary.ifpri.org/cdm/ref/collection/p15738coll2/id/127406

Hatfield, J. L., Boote, K. J., Kimball, B. A., Ziska, L. H., Izaurralde, R. C., Ort, D., Thomson, A. M., \& Wolfe, D. (2011). Climate impacts on agriculture: Implications for crop production. Agronomy Journal, 103(2), 351370. https://doi.org/10.2134/agronj2010.0303

Intergovernmental Panel on Climate Change (IPCC). (2018). Summary for Policymakers. In: Global Warming of $1,5^{\circ}$ C. Intergovernmental Panel on Climate Change (IPCC), 1-24. https://www.ipcc.ch/

Islam, M. A., Masoodi, T. H., Gangoo, S. A., Sofi, P. A., Bhat, G. M., Wani, A. A., Gatoo, A. A., Singh, A., \& Malik, A. R. (2015). Perceptions, attitudes and preferences in agroforestry among rural societies of Kashmir, India. Journal of Applied and Natural Science, 7(2), 976-983. 
https://doi.org/10.31018/jans.v7i2.717

Jama, B., \& Zeila, A. (2005). Agroforestry in the drylands of eastern Africa: A call for action. ICRAF Working Paper - No. 1, 1-38.

Jama, N., Kuntashula, E., \& Samboko, P. C. (2019). Adoption and Impact of the Improved Fallow Technique on Cotton Productivity and Income in Zambia. Sustainable Agriculture Research, 8(2), 1. https://doi.org/10.5539/sar.v8n2p1

Kabwe, G., Bigsby, H., Conference, T., Nelson, C., August, N. Z., Kabwe, G., Bigsby, H., \& Cullen, R. (2009). Factors influencing adoption of agroforestry among smallholder farmers in Zambia Paper presented at the 2009 NZARES Conference smallholder farmers in Zambia.

Kaliba, A. R., Mazvimavi, K., Gregory, T. L., Mgonja, F. M., \& Mgonja, M. (2018). Factors affecting adoption of improved sorghum varieties in Tanzania under information and capital constraints. Agricultural and Food Economics, 6(1). https://doi.org/10.1186/s40100-018-0114-4

Khoza, S., Van Niekerk, D., \& Nemakonde, L. D. (2019). Understanding gender dimensions of climate-smart agriculture adoption in disaster-prone smallholder farming communities in Malawi and Zambia. Disaster Prevention and Management: An International Journal, 28(5), 530-547. https://doi.org/10.1108/DPM-102018-0347

Kuntashula, E., Chabala, L. M., Chibwe, T. K., \& Kaluba, P. (2015). The Effects of Household Wealth on Adoption of Agricultural Related Climate Change Adaptation Strategies in Zambia. 4(4), 88-101. https://doi.org/10.5539/sar.v4n4p88

Lavers, T. (2018). Responding to land-based conflict in Ethiopia: The land rights of Ethnic minorities under federalism. African Affairs, 117(468), 462-484. https://doi.org/10.1093/afraf/ady010

Makate, C. (2019). Local institutions and indigenous knowledge in adoption and scaling of climate-smart agricultural innovations among sub-Saharan smallholder farmers. 270-287. https://doi.org/10.1108/IJCCSM-07-2018-0055

McCarthy, N., \& Brubaker, J. (2014). Climate-Smart Agriculture \& Resource Tenure in sub-Saharan Africa: a Conceptual Framework. September, 26. http://www.fao.org/3/a-i3982e.pdf

Mugure, A., Gutwa Oino, P., \& Sorre, B. M. (2013). Land Ownership and its Impact on Adoption of Agroforestry Practices among Rural Households in Kenya: A Case of Busia County.

Mutua-Mutuku, M., Nguluu, S. N., Akuja, T., Lutta, M., \& Bernard, P. (2017). Factors that influence adoption of integrated soil fertility and water management practices by smallholder farmers in the semi-Arid areas of eastern Kenya. Tropical and Subtropical Agroecosystems, 20(1), 141-153.

Mwangi, M., \& Kariuki, S. (2015). Factors Determining Adoption of New Agricultural Technology by Smallholder Farmers in Developing Countries. Issn, 6(5), 2222-1700. www.iiste.org

Nkhuwa, H., Kuntashula, E., Kalinda, T., \& Chishala, B. (2020). Effects of soil organic resource management practices on crop productivity and household income in Chipata district of Zambia. 12(December), 98109. https://doi.org/10.5897/JAERD2020.1181

Nyasimi, M., Kimeli, P., Sayula, G., Radeny, M., Kinyangi, J., \& Mungai, C. (2017). Adoption and dissemination pathways for climate-smart agriculture technologies and practices for climate-resilient livelihoods in Lushoto, Northeast Tanzania. Climate, 5(3). https://doi.org/10.3390/cli5030063

Padgham, J. (2009). Agricultural Development under a Changing Climate. In Agricultural Development under a Changing Climate. https://doi.org/10.1596/28125

Peters, P. E. (2007). Challenges in Land Tenure and Land Reform in Africa: An Anthropological Perspective. Medical Anthropology Newsletter, 13(2), 31-32.

Rahman, S. A., Imam, M. H., Wachira, S. W., Farhana, K. M., \& Torres, B. (2008). RESEARCH PAPER LAND USE PATTERNS AND THE SCALE OF ADOPTION OF AGROFORESTRY IN THE RURAL LANDSCAPES OF PADMA FLOODPLAIN IN BANGLADESH. 18, 193-207.

Rogers, E. M., \& Everett, M. (n.d.). DIFFUSION OF Third Edition.

Sahin, I., Rogers, F., Rogers, F., \& Rogers, F. (2006). DETAILED REVIEW OF ROGERS ' DIFFUSION OF INNOVATIONS THEORY AND EDUCATIONAL TECHNOLOGY-RELATED STUDIES BASED ON ROGERS'. 5(2).

Shittu, A. M., Kehinde, M. O., Ogunnaike, M. G., \& Oyawole, F. P. (2018). Effects of Land Tenure and Property Rights on Farm Households' Willingness to Accept Incentives to Invest in Measures to Combat Land Degradation in Nigeria. In Agricultural and Resource Economics Review (Vol. 47, Issue 2). https://doi.org/10.1017/age.2018.14

Sosthenes et al. (2012). The impact of land tenure and degradation on adoption of agroforestry in Uluguru mountains forest, Tanzania. Journal of Environmental Sccience and Water Resources, 1(10), 236-242.

State, T. H. E., \& Food, O. F. (2002). 2002 THE STATE OF FOOD AND AGRICULTURE AGRICULTURE AND GLOBAL PUBLIC GOODS AFTER THE EARTH SUMMIT.

Tsige, M., Synnevåg, G., \& Aune, J. B. (2020). Gendered constraints for adopting climate-smart agriculture 
amongst smallholder Ethiopian women farmers. Scientific African, 7, e00250. https://doi.org/10.1016/j.sciaf.2019.e00250

UNDP. (2009). Gender and Gender and (Issue 2017).

WFP. (2018). Focal points: Annual performance report for 2017 Draft decision*. June, 193. https://executiveboard.wfp.org

White, D., Bonilla-Findji, O., Schreeg, L., \& Jarvis, A. (2016). Climate-Smart Agriculture (CSA) within the Feed the Future Project Portfolio of USAID-Zambia: A CCAFS Deep Dive Review. Wageningen, Netherlands: CGIAR Research Program on Climate Change, Agriculture and Food Security (CCAFS), 116. https://cgspace.cgiar.org/handle/10568/81016 